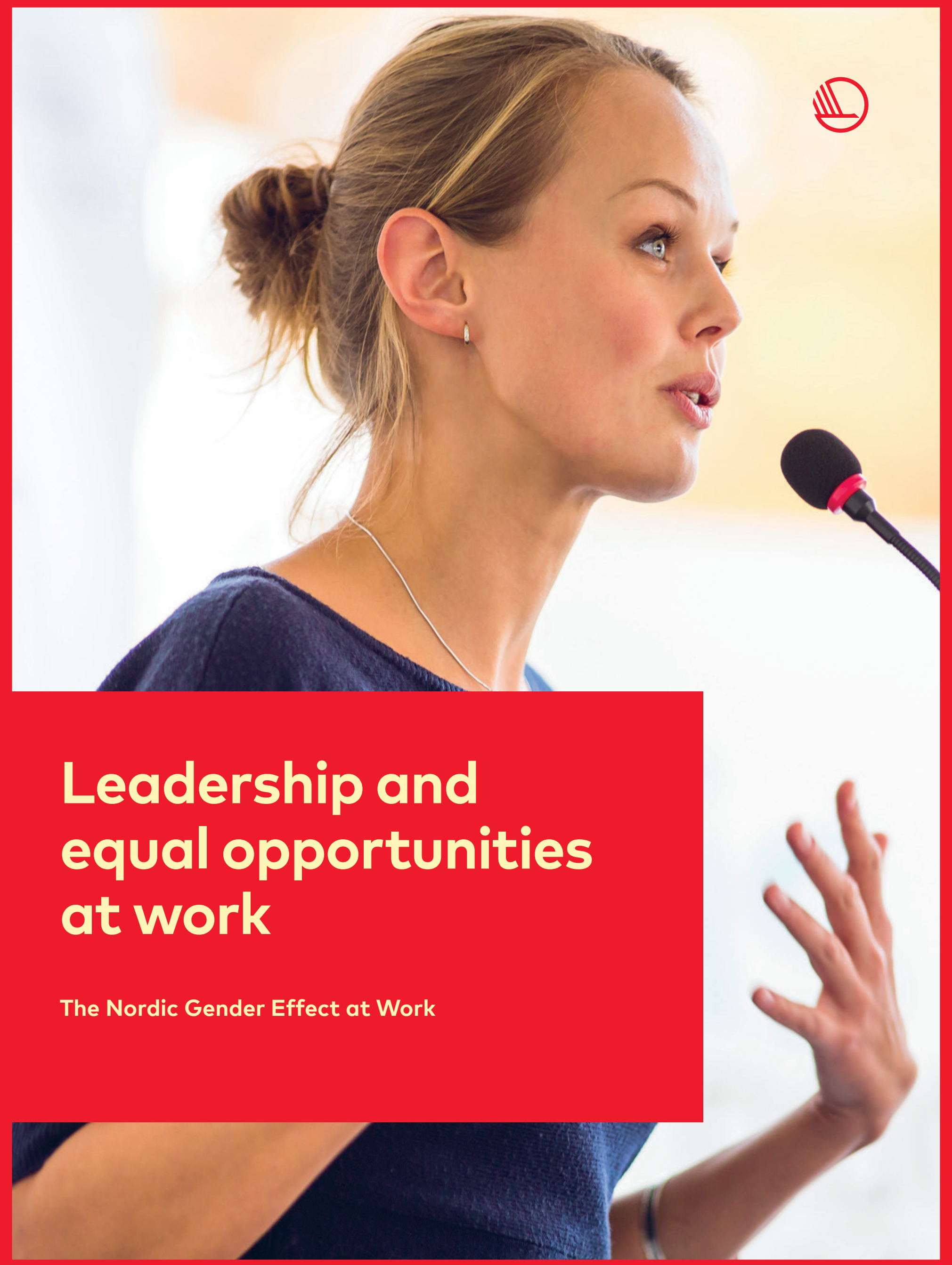


Leadership and equal opportunities at work

The Nordic Gender Effect at Work

Nordic Information on Gender (NIKK)

Nord 2019:057

978-92-893-6410-2 (PDF)

978-92-893-6411-9 (EPUB)

http://doi.org/10.6027/NO2019-057

(c) Nordic Council of Ministers 2019

Layout: Mette Agger Tang

Cover photo: Mostphotos.com

Infographics: Essensen

\section{Nordic co-operation}

Nordic co-operation is one of the world's most extensive forms of regional collaboration, involving Denmark, Finland, Iceland, Norway, Sweden, the Faroe Islands, Greenland, and Åland.

Nordic co-operation has firm traditions in politics, the economy, and culture. It plays an im-portant role in European and international collaboration, and aims at creating a strong Nordic community in a strong Europe.

Nordic co-operation seeks to safeguard Nordic and regional interests and principles in the global community. Shared Nordic values help the region solidify its position as one of the world's most innovative and competitive.

\section{Nordic Council of Ministers}

Nordens Hus

Ved Stranden 18

DK-1061 Copenhagen

www.norden.org

Download Nordic publications at www.norden.org/nordpub 
Investments in gender equality in the labour market have made the Nordic region one of the most prosperous areas of the world. The share of women who work in the Nordic countries is larger than the global average, which is partly the effect of commitments to equal workplaces, subsidised childcare and generous parental leave. With The Nordic Gender Effect at Work briefs, the Nordic region seeks to share its collective experience in promoting gender equality at work, and enable more knowledge sharing and progress towards the UN's 2030 Agenda for Sustainable Development. 


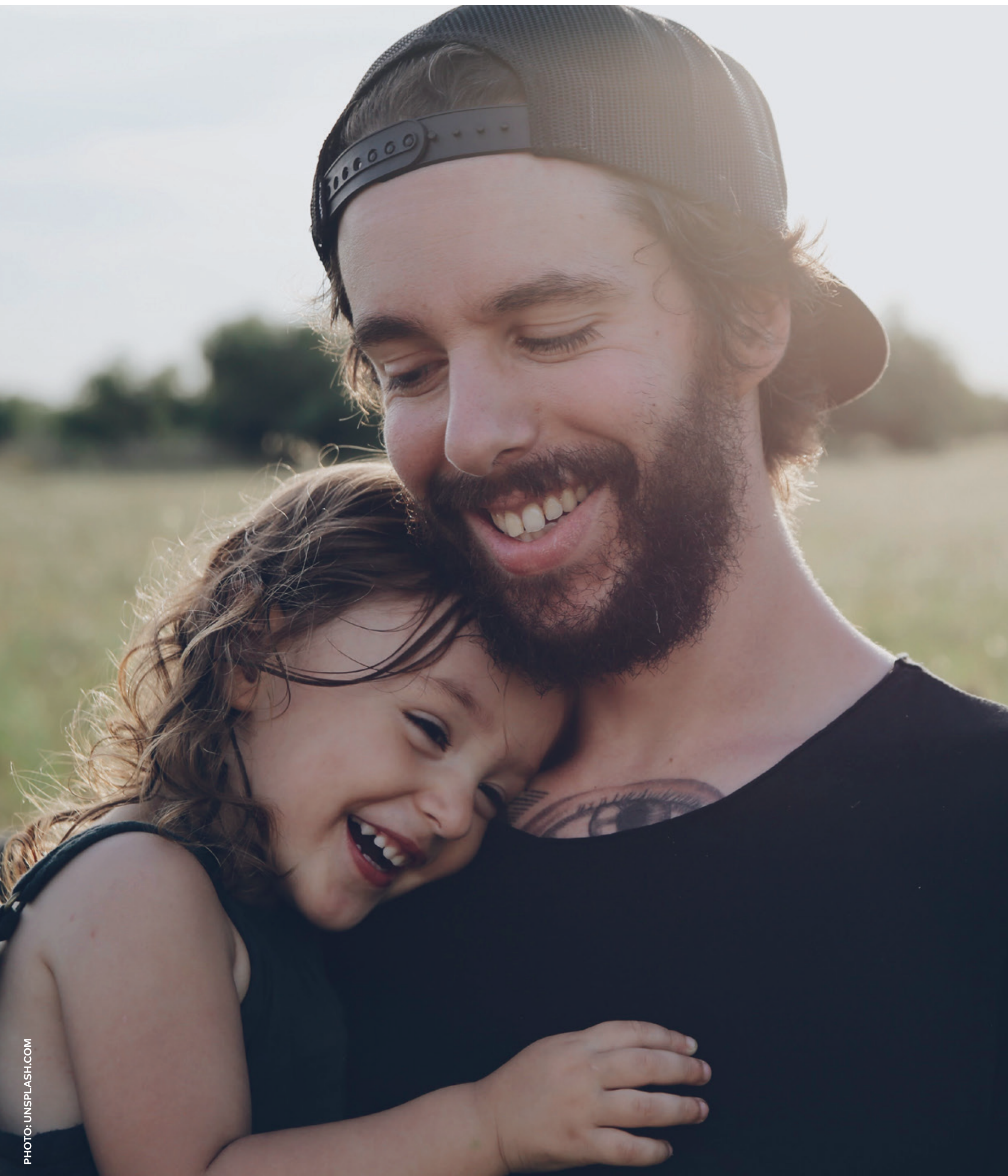




\section{Introduction}

Only half of women in the world engage in paid work. Many do so in poor working conditions with low pay, without access to maternity protection or parental leave. Childcare is often unreliable or unaffordable, and violence and sexual harassment are a reality of many working women's day. These exclusions are a violation of women's basic human rights. What is more, gender inequality at work is economically inefficient and ultimately costly for companies and countries alike.

Promoting gender equality at work is thus not only the right thing to do, but the smart thing to do. The Nordic region can be seen as a case in point. Combined, the five Nordic countries have come to represent the 11th largest economy in the world, not despite their policy commitment to gender equality and social justice, but because of it. Today the Nordic countries are known as financially strong welfare states with good living conditions. However, this has not always been the case.

In the past 100 years, women in the Nordic region have transitioned from living under husbands' guardianships to being financially independent, from not having the right to vote to holding the highest offices in society. The labour movement and the women's rights movement played important roles in making these changes happen, and helped pave the way for new legislation together with progressive policymakers. Descriptions of life in the Nordic countries often reference 'the Nordic model', which is characterised by a political ambition to reduce inequalities and by effective cooperation between the social partners and with collective bargaining in the labour market. Building on this, the Nordic countries have introduced a range of policies since the 1960s that facilitate women's engagement in paid work, as part of a broader policy agenda to advance gender equality and social justice.
Today the Nordic countries lie ahead of the curve on women's participation in the labour force. A significant policy to reach this position was high quality, subsidised childcare for all. The policy incentivised mothers to remain in the workforce after having children, and created a plethora of educational opportunities and jobs in the childcare industry. Enabling and promoting shared parental leave has been another key to prosperity for the Nordics. The countries have even encouraged paternity leave, which sets a path towards more involved fatherhood and happier and healthier families. Nordic employers across industries also recognise that flexible work arrangements do not impede productivity, but rather reduces stress and enables both working women and men to attend to their family responsibilities. It is part of a broader Nordic policy agenda of seeing rights and productivity as two sides of the same coin.

Despite a strong and consistent focus, there is more work to be done. Notably the Nordic countries are grappling with a resilient gender pay gap and a labour market with high levels of occupational segregation. The region does not have all the answers, and in a number of areas (occupational sex-segregation being a case in point) countries in other regions are performing better. The Nordic governments are committed to playing their part in achieving the UN's Sustainable Development Goals (SDGs) by 2030, and seek to enable international knowledge sharing and facilitate a collective improvement in the stride for gender equality.

This brief focuses on leadership and equal workplaces. The Nordic Gender Effect at Work series include briefs on subsidised childcare for all; shared and paid parental leave; flexible work arrangements; and leadership and equal opportunities at work. 


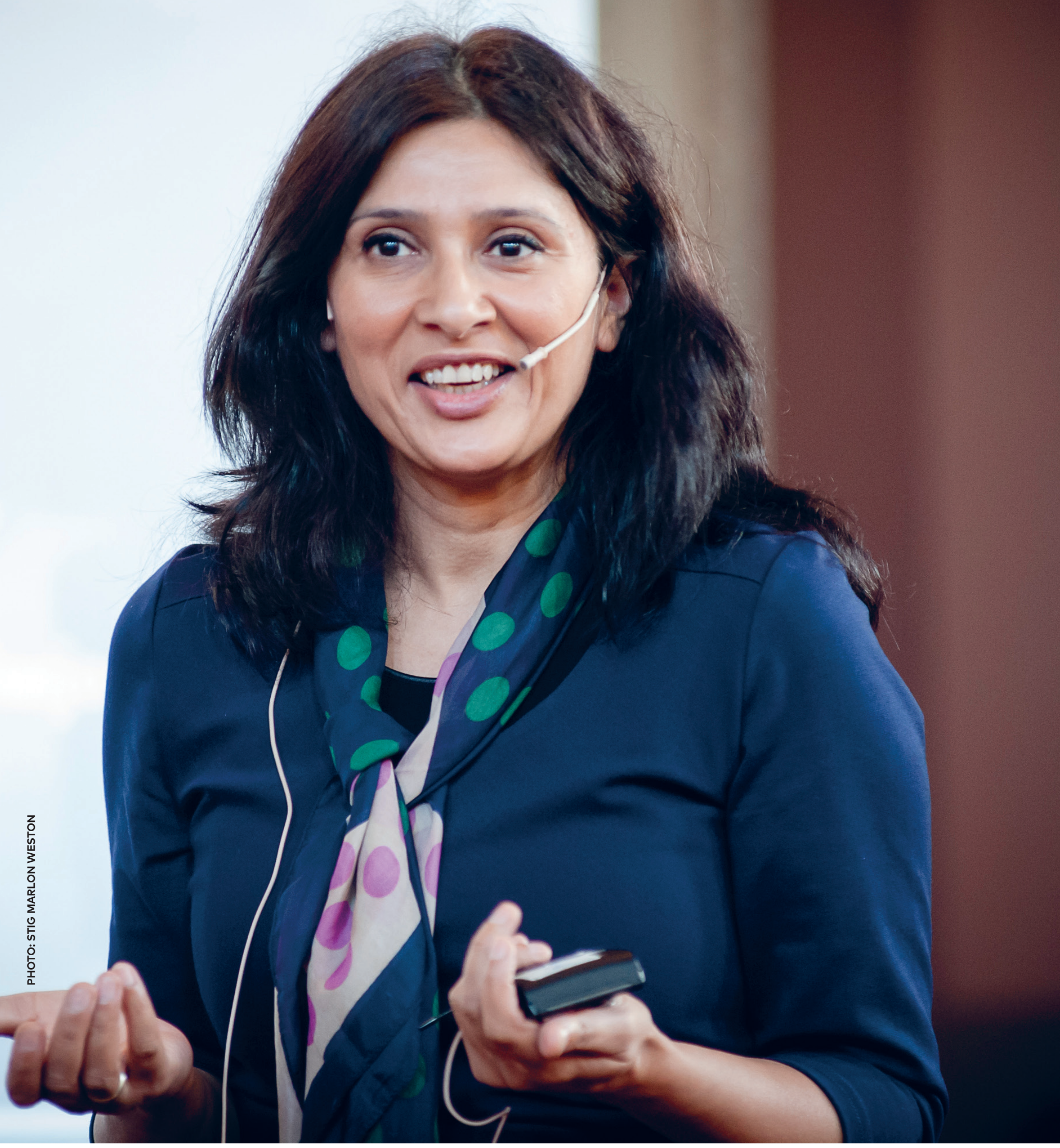




\title{
Leadership and equal opportunities at work
}

\author{
Equal opportunities in the workplace have been high on the Nordic \\ political agenda since the 1970s. Many initiatives have been laun- \\ ched to ensure women and men's equal opportunities at work and \\ for leadership at all levels. Today the Nordic region stands tall in \\ international rankings on gender equality at work.
}

This brief explains what the Nordic countries have done and continue to do to create equal opportunities for women and men at work as well as opportunities for women to advance to leadership positions.

The Nordic countries have long encouraged women's entry into the workforce and striven for a labour market in which women and men can participate on equal terms. All Nordic countries have official gender equality targets, which include specific targets related to the labour market. Men and women have the right to pursue the same jobs and occupations, and it is illegal to discriminate against people because of their sex or gender identity. Nevertheless, women and men continue to face different conditions and perform different work tasks in different sectors, in different positions and with different pay.

\section{Laws and countervailing measures}

As early as 1921, Denmark adopted a law on equal access to employment for men and women, and by the 1970s, the issue of gender equality began to feature on the Nordic political agendas in earnest as all five countries gradually adopted laws and promoted policies to ensure equal opportunities for women and men at work.

Today, all Nordic countries have laws mandating equal pay for work of equal value, as defined by the ILO's Equal Pay Convention (C100). There is also extensive legal protection against discrimination in workplace. For example, it is illegal to dismiss a woman because she is pregnant or has given birth. Both parents are protected from dismissal because they have made use of or wish to make use of their right to maternity, paternity or parental leave. Sexual harassment is also legally prohibited, both in the workplace and in society at large. In addition, in several Nordic countries, employers are required to actively promote gender equality and equal treatment to prevent discrimination. The details of the regulations vary somewhat across the countries, however.

In Sweden, employers are required to both prevent discrimination and be proactive in promoting equality. They must for example develop guidelines to prevent sexual harassment and carry out annual salary assessments. In the salary assessments, an employer may examine salary criteria or

\footnotetext{
$\leftarrow \quad$ "Companies that mainly focus on white men in top management will have difficulties competing on the international market," says Loveleen Rihel Brenna, author, opinion leader and managing director of her own company Seema in Oslo, Norway. Seema trains and advises companies, politicians and organisations on how diversity and gender equality in management makes them more sustainable and profitable. Brenna recently helped devise the new national standard for diversity in management in Norway, and has written a handbook on the subject.
} 
bonus schemes to ensure that no one is disadvantaged due to their sex. Employers must also analyse the causes of any discrimination that is unveiled and then take appropriate action.

Icelandic legislation stipulates that employers must take particular measures to protect employees from sexual harassment in the workplace. Finland requires employers to encourage both women and men to apply for vacant positions. For example, an employer may write in a job advertisement that persons of the underrepresented sex are particularly encouraged to apply. According to Finnish law, employers should create working conditions that are appropriate for both women and men, and ensure that staff facilities are equally useful regardless of gender and needs.

\section{Iceland legislating against gender pay gap}

Just like in the rest of the world, women in the Nordic countries earn less than their male counterparts. Nordic labour markets are characterised by high rates of women's employment, but also by high rates of occupational segregation. And jobs in the sectors employing a majority of women, such as the education and care sectors, tend to be low paid, whereas those sectors dominated by men are often highly paid. Thus, it is to some extent the high rates of women's labour force participation predominantly in the public sector that has led to the relatively large gender pay gaps. In contrast countries with low levels of women's labour force participation tend to have a small gender pay gap, as the minority of women who do work tend to be more equally spread across the sectors of the economy.

Various efforts have been made to reduce the gender pay gap, without much effect. However, the Icelandic government, in consultation with trade unions and employers' organisations, broke new ground by developing an equal pay standard and adopting it into a new law. The new law, which came into effect 1st January 2018, requires all employers, public as well as private, with at least 25 employees to annually certify their salary structures according to the equal pay standard. The law is introduced in stages over a 3-year period. The goal is to eliminate the pay gap between women and men by 2022 . It stipulates that employers must identify the work tasks a position entails and assign a value accordingly. The underlying idea is that salaries should be determined based on position and not the person holding it, and thus the risk for salary discrimination is reduced. The law also makes the setting of salaries clearer and more transparent. As with other standards, the Icelandic equal pay standard has been developed so that it can be replicated elsewhere.

\section{Women in leadership positions}

The Nordic countries have been proactive in promoting the equal representation of women and men in

\section{Mainstreaming as a tool}

\author{
All Nordic countries use gender mainstrea- \\ ming as a strategy to achieve nationally \\ declared gender equality goals. Gender \\ mainstreaming is a way to plan the work in an \\ organisation so that no decision is ever made \\ without first considering how it will \\ affect the balance of power between \\ women and men.
}

\section{Highly educated women}

In the Nordic countries, the proportion of women with university education is larger than the proportion of men. Sixty-one per cent of those who obtain a university degree are women. 


\section{Unadjusted gender pay gap}

per cent (2017)
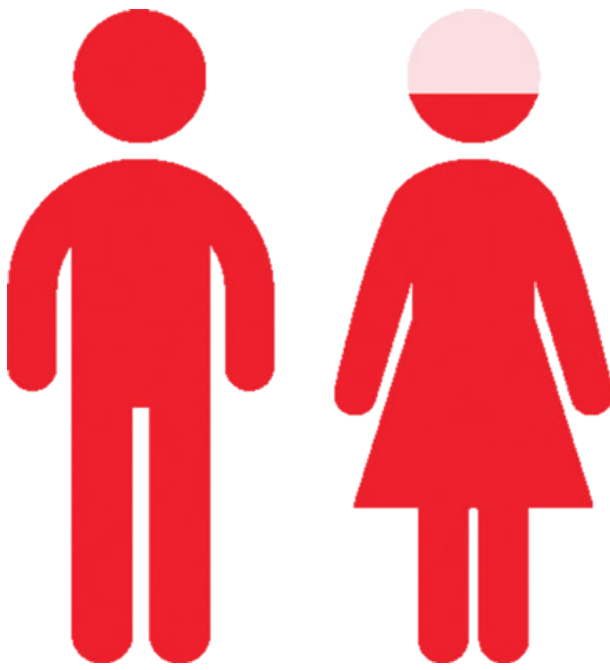

14.3

NORDIC REGION

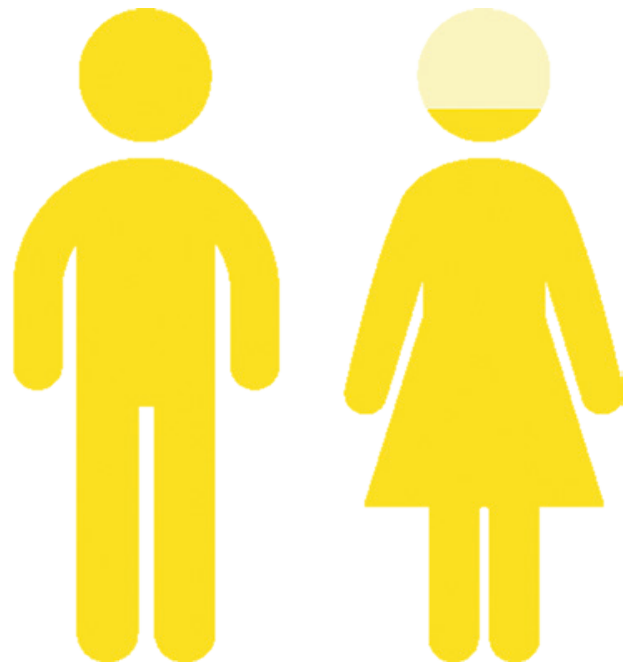

16.0

EU28

In the Nordic countries, data on gender equality is gathered and evaluated. Access Nordic gender equality indicators here: norden.org/statistics

Source: Nordic Statistics 2019

D5

As CEO, you can really make a difference when it comes to gender equality. I believe that all company boards should demand gender equality from their CEOs, just like they demand results in the form of balanced budgets

Bjarni Bjarnason, CEO of Reykjavik Energy. 
positions of power. Iceland stands out historically when it comes to choosing women for the highest political positions. Vigdís Finnbogadóttir became Iceland's president in 1980 and held the position for 16 years. She was then the world's first democratically elected female head of state. Today, all the Nordic countries have much higher proportions of female members of parliament than the international average. At present, Norway, Iceland and Åland have female prime ministers, while Denmark, Finland and Greenland have had female prime ministers (and Finland and Iceland women presidents) in the past. The Nordic countries have also actively promoted female representation at the highest decision-making levels, such as on company boards of both public and private enterprises. Similar initiatives have also been taken in the autonomous Nordic areas. Greenland has special rules regarding equal representation of women and men when appointing members to public committees or to the boards of state-owned companies. When the government appoints board members, they must ensure an even gender distribution. As a result, state-owned Greenlandic companies have more women than men on their boards.

Norway was the first country in the world to introduce a gender parity quota law for company boards. According to the law, which came into force in 2008, all company boards must consist of at least 40 per cent women. Several effects have already been observed. When the law was enacted, only around six per cent of company board members were women; today, the share is over 40 per cent. Moreover, the appointment of board members has become more transparent and clearly structured, and the attitudes to gender balance have become more positive in corporate circles. The Norwegian quota law has also contributed to the initiation of a European debate on the male dominance of company boards, and indeed more generally in the business community. Several countries have been inspired by the Norwegian model. By 2016, eight OECD countries had adopted similar quota laws for the boards of listed and/or state-owned companies: Belgium, France, Greece, Iceland, Israel, Italy, Germany and Austria.

\section{Still few women at the top}

Despite ongoing efforts, a troubling pattern remains: the higher up the hierarchy you look, the more men you will see. This is particularly true in the private sector. Research from Norway shows that the lack of women in leadership positions in the private sector can be linked to the uneven distribution of parental leave and childcare responsibilities at home. Family policy interventions may be necessary and desirable, but as long as women take advantage of them in significantly greater numbers than men, they can become a gender inequality trap.

Studies of the Norwegian quota law show that the improved gender balance on company boards has

\section{Nordic challenges}

The Nordic countries have come a long way in ensuring equal opportunities in the workplace as well as in promoting women's leadership, yet several important challenges remain. We want to invite others to a discussion on how they can be effectively dealt with.

\section{Differences in pay}

The gender pay gap in the Nordic countries remains stubbornly consistent, despite the fact that the countries have come a long way in a global context when it comes to gender equality in the workplace.

\section{Distribution of unpaid housework}

Women in the Nordic countries spend considerably more time than men on unpaid housework, childrearing and elder-care. Research shows that it is easier for women to pursue a career when there is a more 
not spread to top management. The same trend can be seen in Iceland. However, Norwegian authorities have given priority to monitoring the gender balance at the top management levels through the development of CORE - Norwegian Gender Balance Scorecard, which maps the gender balance of the executive committees of the 100 and 200 largest companies in Norway over time. In 2017 there were 20 per cent women in top management positions in Norway's 200 largest companies and 28 per cent women on corporate boards. Eighty-six of these companies were covered by the board quota legislation.

The male dominance at the top levels of businesses and other organisations gives men greater access to power and privilege. It also gives them more influence over how workplaces and the entire labour market are organised, which has implications for women's and men's opportunities for advancement, salaries, health and life at large. In Sweden, more women than men hold management positions in the public sector, and vice versa in the private sector. However, compared with their male counterparts in the private sector, research shows that female managers in the public sector have higher levels of education and more responsibility. They also have lower pay, despite being in charge of significantly more people. gender-equal division of household chores.

How can men be persuaded to do more

unpaid work at home?

\section{The limitations of quota rules}

Studies of the Norwegian quota law show that the improved gender balance seen in company boards has not spread to more women CEOs or other managers. One reason for this is that the business world is characte- rised by a wide range of leadership standards and traits that are typically (perhaps stereotypically) associated with men. How can we foster an environment where both women and men can hold top management positions? 
TRUE STORIES

\section{ICELAND: ENERGY COMPANY WALKS THE TALK ON GENDER EQUALITY}

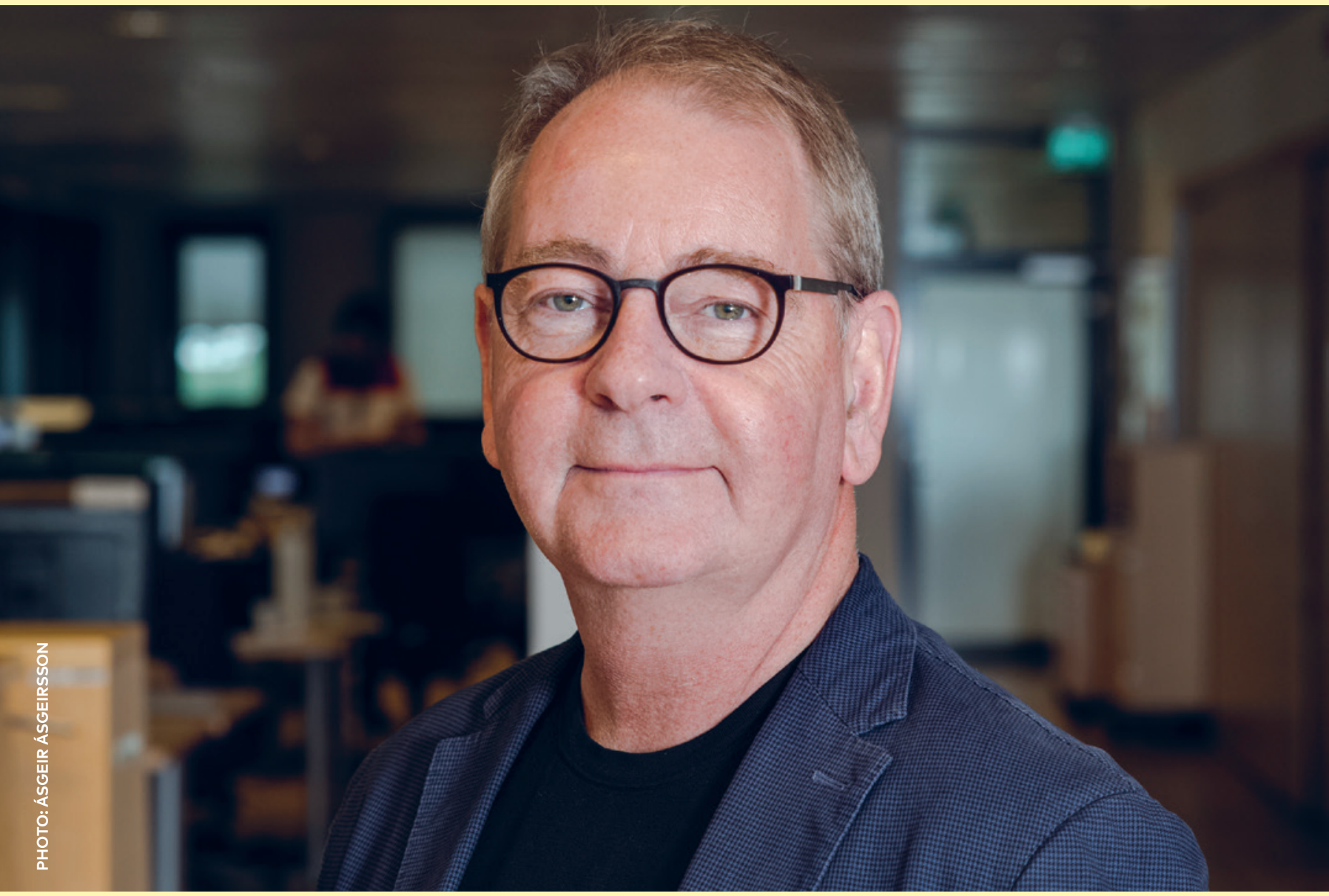

$\uparrow \quad$ Bjarni Bjarnason, CEO of Reykjavik Energy 


\section{Reykjavik Energy has received two major gender equality awards for its efforts, and the staff are proud of their workplace.}

Iceland's municipally owned energy company Reykjavik Energy is over 100 years old. It provides two-thirds of the island nation with drinking water, heating, electricity, wastewater management and other services. When Bjarni Bjarnason, CEO, took over the company in 2011 , it was run-down and had a poor reputation. Seventy-five per cent of the managers were men and there were large gender differences in salaries. Bjarnason decided early to create a gender-equal company. Today, 54 per cent of the management staff are women and the gender pay gap has been almost eliminated. In 2019, the gender pay gap was 0.5 per cent in favor of men. Reykjavik Energy measures the gap monthly to keep it within 1 per cent in either direction. The company, which used to be on the brink of bankruptcy, has become an attractive and admired employer.

'The first thing was easy to fix, since the company already had plenty of highly skilled women. As for the differences in pay, a team of external experts developed a tool that helped us identify and correct unfair salaries,' says Bjarnason.

Reykjavik Energy was a traditionally male-dominated workplace. To review structures and the work environment, a gender equality expert was asked to analyse the company. This person looked at everything from the company jargon to the paintings on the walls. The work was supplemented with an annual staff survey aimed at assessing the occurrence of sexual harassment and bullying.

'We measure and take action accordingly. \#MeToo was a wake-up call for many. Reykjavik Energy responded by holding mandatory workshops for all employees on sexual harassment and how to eliminate it. The movement led to changes in labor regulations in Iceland, which led to changes in our procedures,' says Bjarnason.

The company has also taken the initiative to break the male dominance in the energy sector by starting a stand-alone course for upper-secondary students. The course is held at the energy company and half of the participants are girls.

'The students get to try all sorts of things, like working in the power stations. It's great to see an old welder teach a group of 16-year-old girls. The course has led to more girls studying to become electricians,' says Bjarnason.

According to him, the gender equality initiative has had enormously positive effects. 


\section{TRUE STORIES}

\section{FINLAND: CONGRATS, YOU HAVE AN ALL-MALE PANEL!}

The Finnish initiative 'Congrats, you have an all-male panel!' has become a viral success. People from around the world submit their contribution to the Tumblr page, which gathers examples of expert panels consisting of only men.

The person behind the Tumblr account is Saara Särmä, Doctor in political science at the University of Tampere.

'I saw it everywhere in academia. The more serious the topic, the more men. At the same time, I worked with a large number of highly knowledgeable women who are not part of the panels. It led me to take action,' says Särmä.

People are invited to submit their own examples of all-male panels to the Tumblr page. The posts are complemented with a picture of Baywatch star David Hasselhoff giving a thumbs-up. The account currently has 2,000 posts and about 150,000 views.

'I think the humour made my Tumblr page go viral. It makes it easier for people to take in the message than if I would have been angry and critical,' says Särmä.

She has received a broadly positive response, including from men, many of whom have contacted her and said they appreciate the initiative. They have told her that they have never thought about this and that they have started to decline offers to serve on expert panels to make room for more women,' she says.

Särmä receives contributions from around the world, including Australia, Europe, Latin America and the United States. She says that a similar website has been launched in Latin America, and there is also a new 'good panel' initiative in Europe, which gathers positive examples of what a good, balanced panel may look like.

'Those who organise events need to start thinking outside the box and focus more on diversity and gender equality when it comes to representation. We need to get away from the male stereotype, or else we will only use half of the resources that the population has to offer', says Särmä. 


\section{SWEDEN: CONFRONTING MACHO CULTURE IN CONSTRUCTION}

\section{The construction industry is one of Sweden's least gender-equal occupational sectors. Of 100 construction workers, 99 are men.}

The problems include outdated attitudes and sexist jargon. The Stop the Macho Culture campaign was launched in 2015 by Byggcheferna, the Swedish association of construction managers, and the Swedish Building Workers' Union.

'The campaign is still very important in 2019. Our material has become a huge success and other male-dominated industries, such as the Swedish Armed Forces and police, have reached out to us wanting to know how we have gone about it', says Kajsa Hessel, chair of Byggcheferna.

It all began with a survey of women managers in the construction industry. Eighty per cent responded that their workplaces are characterised by a traditional male locker room culture and that they are not treated the same as men. Fifty per cent had experienced sexual harassment either in person or by watching a colleague be targeted. Many respondents said that both men and women are leaving the industry because of the macho culture. The goal of the campaign is to stop the trend, and create a construction industry where everybody is treated fairly.

The campaign's first step was to launch posters and films where children read out loud real-life sexist quotes from the industry. The campaign received a lot of attention, and the film has attracted more than 500,000 views and is used today as workplace introduction for new employees at the major construction companies. The following step was a workshop tour across Sweden, where over 1,000 people from various construction sites gathered to discuss macho culture. A manual and a toolbox were developed, with the latter being a game with key questions and situations from real-life. The idea is for people to read statements and discuss them in groups.

Interest in the campaign and its material has grown. Today a knowledge portal has been built, where all the material is collected. 'We could be out there constantly lecturing. Thanks to \#MeToo, awareness has grown. When we started the campaign, there was a skepticism from industry colleagues. It doesn't exist any longer. I feel that there is an understanding that we need to change the jargon in order to become a more attractive industry', says Hessel. 


\section{Sources}

Hardoy, I, Schøne P, Misje Østbakken K. (2017). Children and the gender gap in management. Labour Economics.

Løvslett Danbolt, I. (2016). All about business: Nordic women on boards and in leadership.

Denmark: Nordic Council of Ministers.

Nordic Information on Gender (NIKK), (2017).

Gender Equality Policy.

Nordic Information on Gender (NIKK), (2017). Iceland intent on eliminating the gender pay gap.

Nordic Statistics, (2019). Gender Equality Indicators.

OECD, (2017). The pursuit of gender equality: An uphill battle. Paris: OECD Publishing.

Regnö, K. (2013). Det osynliggjorda ledarskapet. Kvinnliga chefer i majoritet. (Doctoral thesis).

Stockholm: KTH Royal Institute of Technology.

Teigen, M. (Ed.), (2015): Virkninger av kjønnskvotering i norsk næringsliv. Oslo: Gyldendal Akademisk.

This brief is also based on interviews with researchers. 


\section{About}

Nordic Solutions to Global Challenges is an initiative by the Nordic prime ministers to enable knowledge sharing and exchange under three pillars, namely: Nordic Green, the Nordic Gender Effect and Nordic Food \& Welfare. The initiative is part of the Nordic region's effort to promote progress towards the UN's Sustainable Development Goals through the Nordic Council of Ministers, the official arm of Nordic governmental cooperation. The Nordic Gender Effect at Work is the name of the prime ministers' flagship to promote gender equality as a goal in its own right, and as a prerequisite for decent work and economic growth.

This series of briefs was prepared by Nordic Information on Gender (NIKK). NIKK is a knowledge centre, which collects and disseminates Nordic research, knowledge and policy in the area of gender equality.

The briefs describe how the Nordic countries have facilitated women's participation in the labour market and promoted gender equality at large. The introduction provides an overview of the Nordic welfare model and a historical context for the solutions that have been developed in the Nordic region over time. There are four specific briefs, which outline policies and experiences on subsidised childcare for all, shared and paid parental leave, flexible work arrangements and measures to achieve gender balance in leadership and equal opportunities at work.

\section{Acknowledgements}

The Nordic Council of Ministers would like to acknowledge and give special thanks to the International Trade Union Confederation (ITUC) and UN Women for contributing with invaluable feedback to the briefs, and to the International Labour Organization (ILO) for the collaboration on the Global Dialogue on Gender Equality in the World of Work, which provided an invaluable foundation for the series.

Thanks to all contributors including author Ida Måwe, flagship project initiator Julia Fäldt Wahengo, lead editors Line Christmas Møller, Elin Engström and Anna Rosenberg, as well as Ulrika Jansson, Kajsa Widegren, Maria Grönroos, Josefine Alvunger, Sanna Schiller, Ned Lawton, Ulla Agerskov, Frida Thomassen, Idah Klint, Sigtona Halrynjo, Johanna Lammi-Taskula, Ingólfur V. Gíslason, Ulla Björnberg, Tine Rostgaard, Charlotta Niemistö, as well as the flagship steering committee and the Nordic Committee of Senior Officials for Gender Equality.

\author{
For more: \\ norden.org/nordicgendereffect and nikk.no
}


Nordic Council of Ministers

Nordens Hus

Ved Stranden 18

DK-1061 Copenhagen

www.norden.org

Promoting gender equality at work is not only a matter of rights; it is the smart thing to do from the perspective of inclusive growth. The Nordic region is a case in point, as it has come to represent the 11th largest economy in the world, not despite policy commitments to gender equality and social justice, but because of it. The Nordic countries have robust economies and good living conditions, where both women and men have high labour force participation rates. However, the gender pay gap is persistent and occupational segregation continues to hinder gender equality.

The Nordic Gender Effect at Work briefs share the collective Nordic experience in investing in gender equality including parental leave, childcare, flexible work arrangements, leadership and equal opportunities at work, and seek to make further progress through cooperation. 